\title{
Use of Fermented Azolla in Diet of Tilapia Fry (Oreochromis niloticus)
}

\author{
S. K. Hundare*, D. I. Pathan and A. B. Ranadive
}

Collage of Fisheries, Shirgaon, Ratnagiri, Maharashtra (415 629), India

\section{Corresponding Author}

S. K. Hundare

e-mail: sagarhundare7@gmail.com

\section{Article History}

Article ID: AR1925

Received in $29^{\text {th }}$ October, 2018

Received in revised form $12^{\text {th }}$ November, 2018

Accepted in final form $14^{\text {th }}$ November, 2018

\begin{abstract}
The present study was undertaken to evaluate the effect of fermented azolla as fish meal substitute in the tilapia fry diet (Oreochromis niloticus) on growth performance, survival and feed utilization. In the experiment, the fry length initially ranging between $(2.160 \pm 0.090 \mathrm{~cm}$ and $2.540 \pm 0.060 \mathrm{~cm})$ and weight initially ranging between $(0.190 \pm 0.010 \mathrm{~g}$ and $0.210 \pm 0.010 \mathrm{~g})$ were fed on practical basal diet ( $30 \%$ crude protein) in the form of pellet during rearing period of 60 days. The fermented azolla were incorporated in the experimental diet at various levels such as $0 \%$ azolla, $10 \%$ fermented azolla, $20 \%$ fermented azolla and $30 \%$ fermented azolla to formulate four different test diets along with control diet. (Basal diet, without incorporation of fermented azolla, was used as control diet). The experimental fishes were fed with the experimental diet at of $7 \%$ of the body weight twice a day. Among the experimental treatments, the treatment $20 \%$ fermented azolla showed significantly higher growth parameters such as length gain (178.586 $\pm 11.313 \%)$, weight gain (1346.770 $\pm 70.251 \%)$, specific growth rate $(4.449 \pm 0.083 \%)$, average daily growth $(2.840 \pm 0.057 \%)$ and survival $(95.556 \pm 2.222 \%)$. The feed utilization in terms of feed conversion ratio $(1.236 \pm 0.030 \%)$ was significantly lower in $20 \%$ fermented azolla than control group, whereas protein efficiency ratio $(4.145 \pm 0.169)$ in $20 \%$ fermented azolla showed significantly higher than that of other treatments.
\end{abstract}

Keywords: Tilapia, fermented azolla, growth, survival

\section{Introduction}

In broad terms, aquaculture production systems used for producing these aquatic animals and plants can be divided into feed-dependent systems or fed aquaculture (e.g. finfish and crustaceans) and non-fed aquaculture systems, where culture is predominately dependent on the natural environment for food, e.g. aquatic plants and molluscs (FAO, 2016). In Asia, fed aquaculture accounted for $54 \%$ of the region's total aquaculture production, indicating that almost half of Asia's aquaculture production comes from non-fed aquaculture. In contrast to the Asian situation, finfish and crustacean aquaculture production in Europe is $100 \%$ dependent on aquafeeds.

Asia is the largest global consumer of aquafeed ingredients (FAO, 2016). Aquaculture production, mainly of crustaceans and finfish, relies on farm-made or complete industrial diets. About two third of protein in aquatic diets comes from fish meal and its feeding value has caused its extensive use in aquaculture diets. Thus, with expansion of aquaculture industry, demand for fish feed has been increased with a huge pressure on fish meal industry. The reduction in catches of pelagic fishes, the sole resources of quality fish meal has resulted in rapid hike in prices which ultimately affected feed cost, thereby increase in operational cost of farming (FAO, 2016).

Fish nutritionists have made several attempts to partially or totally replace fish meal with less expensive, locally available protein sources. Due to the current high cost of fish meal, there is an intense pressure to re-evaluate common alternative protein sources to determine how best to use them in preparing low fish meal aquafeeds (Hardy and Tacon, 2002). There are several protein sources that have the potential of replacing fishmeal in aquaculture feeds without affecting the growth performance of fish (Tacon and Metian, 2009). In recent years, utilization of aquatic plants and weeds having high food values as feed ingredients has taken a new dimensions in producing the much required animal protein at low cost. The cost of production of aquafeed can be reduced using this ecofriendly and sustainable resources (Gangadhar et al., 2015).

Azolla has a higher crude protein content (ranging from 19 to $30 \%$ ) than most green forage crops and aquatic macrophytes and rather favorable essential amino acid (EAA) composition for animal nutrition (rich in lysine), it has also attracted the 
attention of livestock, poultry and fish farmers (Cagauan and Pullin, 1991). Azolla seems to be rich in some vitamins, notably carotenes and vitamin A (Leonard, 1997 and Fiogbe et al., 2004).

Expansion of Tilapia culture is attributed to high resistance to diseases, ability to survive at low oxygen tensions and ability to feed on wide range of foods. Even though, slight variations exist among tilapia species, nutrient requirements are primarily affected by the size of the fish (El-Sayed and Teshima, 1992). The global tilapia production in 2015 is 5.6 million tonnes and Asia contributes $4.1 \mathrm{mt}$ in which Nile tilapia contributed $2.8 \mathrm{mt}$ (FAO, 2017). The importance of Nile tilapia as an inexpensive protein source in rural communities, its geographical distribution, economic potential ability to reproduce in captivity, availability and in some countries inexpensive market price (Landau, 1992) has made Nile tilapia a preferred fish species for culture in many parts of the world (Fasakin et al., 2008).

A nutrient requirement for optimum growth for tilapia is dependent upon the quality of source, fish size or age and energy contents of the diets. The average protein requirement was varies from 45-50 (Stickney, 1997). The minimum requirement of dietary lipid in tilapia diets is $5 \%$ but improved growth and protein utilization efficiency has been reported for diets with $10 \%-15 \%$ ( $\mathrm{Ng}$ and Chong, 2004). To improve the nutritional value of azolla for fish and subsequently to increase their incorporation level into fish diets, it is necessary to ferment the ingredient to improve rate of digestibility (Velasquez et al., 2011).

Research studies have shown that the protein of azolla plant is $23 \%-30 \%$ which includes $55 \%$ of the amino acid (Gokcinar and Bekcan, 2015). Considering the nutritional importance of azolla in fish diets, an attempt was made in the present study to replace fish meal partially by fermented azolla and to evaluate its effect on growth, survival, feed conversion ratio (FCR), feed efficiency ratio (FER) and protein efficiency ratio (PER) of Tilapia.

\section{Materials and Methods}

The experiment was conducted in wet laboratory of College of Fisheries, Shirgoan, Ratnagiri. Fry of Oreochromis niloticus (Nile tilapia) ranging from $1.8 \pm 0.0098 \mathrm{~cm}$ to $2.0 \pm 0.0098 \mathrm{~cm}$ and $0.0552 \pm 0.0025 \mathrm{~g}$ to $0.91 \pm 0.0025 \mathrm{~g}$ in length and weight respectively were obtained from Hans aquarium (Hasan Mhaslai, Gove village, Post- Pugaon, Tal- Roha, Dist- Raigad, Maharashtra, India). After transportation, acclimatization of fry was carried out to the lab conditions for a period of two weeks in 500 I capacity high density polyethylene (HDPE) circular tanks. Pelleted feed containing 30\% CP was fed three times in day $(07: 00,02.00$ and 20:00 h) at the rate of $7 \%$ of body weight per day (Bag and Mahapatra, 2012). About 20 to $30 \%$ water exchange was carried out daily. Uneaten feed and faecal matter was removed by siphoning water before feeding. After acclimatization to laboratory conditions, initial length and weight of fishes were recorded before initiation of experiment. For the experiment, twenty one HDPE circular tanks having water holding capacity of 110 I were selected. Each tank was cleaned properly and filled up to the capacity of $100 \mathrm{~L}$, for the experiment. The stocking density 30 fishes $\operatorname{tank}^{-1}$ was maintained during rearing period of 60 days.

A pelleted diet was prepared by using locally available feed ingredients. The proximate analysis of each ingredient was carried out (Table 1) to decide its inclusion rate in the basal diet containing $30 \%$ crude protein. After drying, grinding of each ingredient was carried out using electric grinder. The powder was sieved through 80 mesh to obtain fine powder required

\begin{tabular}{llllllll}
\hline \multicolumn{7}{l}{ Table 1: Proximate composition of ingredients used in experimental diets } \\
\hline Sl. No. & Ingredients & Protein & Lipid & Fibre & Moisture & Ash & NFE \\
\hline 1. & Fish meal & 52.89 & 5.78 & 3.11 & 9.8 & 21.90 & 6.49 \\
2. & Soybean meal & 42.00 & 3.50 & 6.50 & 8.70 & 6.00 & 33.3 \\
3. & Rice bran & 21.65 & 1.82 & 8.43 & 9.6 & 12.08 & 46.42 \\
4. & Azolla & 28.59 & 3.47 & 15.71 & 10.1 & 15.76 & 26.37 \\
5. & Groundnut oil cake & 48.01 & 9.46 & 5.96 & 10.4 & 10.03 & 16.14 \\
6. & Maize flour & 16.27 & 2.76 & 1.36 & 9.0 & 4.75 & 65.86 \\
\hline
\end{tabular}

for feed formulation. The inclusion levels of ingredients in diet are shown in Table 2. The different ingredients were weighed separately and mixed thoroughly. Dough of mixed ingredients was prepared by addition of water at the rate of $100 \mathrm{ml} 100$ $\mathrm{g}^{-1}$ of feed mixture which was steam cooked for 15 minutes and cooled at room temperature $\left(30^{\circ} \mathrm{C}\right)$. The cooled dough was pressed through pellet machine to prepare pellets of 1.0 $\mathrm{mm}$ diameter. The pellets were spread uniformly on polythene sheet and kept at room temperature for cooling (Murkar,
2011). After 24 hours, pellets were separated out from the polythene sheet and oven-dried at $65{ }^{\circ} \mathrm{C}$ for 2 hours. After cooling, the pellets were packed in plastic pouches and stored in dry place.There are four iso-nitrogenous (CP 30\%) practical diets were prepared (Table 3). Basal diet containing fish meal was treated as control while in remaining treatments, fish meal was substituted by $10 \%$ fermented azolla $\left(T_{1}\right), 20 \%$ fermented azolla $\left(\mathrm{T}_{2}\right)$ and $30 \%$ fermented azolla $\left(\mathrm{T}_{3}\right)$.

Freshly harvested azolla (Azolla pinnata) was washed 


\begin{tabular}{llcccc}
\hline \multicolumn{6}{c}{ Table 2: \% composition of experimental diets } \\
\hline S I. & Ingredients & $\begin{array}{c}\text { Control } \\
\text { diet }\end{array}$ & \multicolumn{4}{c}{$\begin{array}{c}\text { Fermented } \\
\text { azolla feed }\end{array}$} \\
\cline { 3 - 6 } & & $\mathrm{T}_{0}$ & $\mathrm{~T}_{1}$ & $\mathrm{~T}_{2}$ & $\mathrm{~T}_{3}$ \\
\hline 1. & Fish meal (59\% CP)a & 20 & 18 & 16 & 14 \\
2. & Soybean meal (42\% CP)a & 15 & 16 & 17 & 18 \\
3. & Groundnut oil cake & 15 & 15 & 15 & 15 \\
4. & Azolla & 0 & 2 & 4 & 6 \\
5. & Rice bran & 24 & 22 & 20 & 18 \\
6. & Maize flour & 25 & 26 & 27 & 28 \\
7 & Salt & 1 & 1 & 1 & 1 \\
\hline
\end{tabular}

Table 3: Proximate composition (Dry weight basis) of experimental diets

\begin{tabular}{lcccc}
\hline $\begin{array}{l}\text { Proximate Compo- } \\
\text { sition (\% ) on dry } \\
\text { weight basis }\end{array}$ & $\mathrm{T}_{0}$ & $\mathrm{~T}_{1}$ & $\mathrm{~T}_{2}$ & $\mathrm{~T}_{3}$ \\
\hline Crude protein & 30.81 & 30.81 & 30.25 & 30.6 \\
Crude lipid & 5.42 & 5.42 & 5.63 & 5.45 \\
Crude ash & 6.5 & 6.58 & 6.8 & 7.1 \\
Crude fiber & 15.16 & 15.34 & 16.34 & 15.94 \\
NFE & 42.11 & 41.85 & 40.98 & 40.91 \\
Gross energy (MJ & 1693.21 & 1688.64 & 1668.29 & 1668.27 \\
$\mathrm{~g}^{-1}$ ) & & & & \\
\hline
\end{tabular}

thoroughly with tap water and kept in a airtight container. To initiate fermentation process, $5 \%$ yeast was added and mixed thoroughly. Fermentation process was carried out for four days in dark as per the protocol suggested byUtomo and Ekasari (2011). A fine paste was made after complete fermentation for its inclusion in diet, as feed ingredient.

\subsection{Water quality parameters}

Analyses of water quality parameters such as dissolved oxygen (DO), total alkalinity and free carbon dioxide (free $\mathrm{CO}_{2}$ ) were estimated weekly using methods given by APHA (2005) and Boyd (1981). The water temperature and $\mathrm{pH}$ were recorded daily by using thermometer and Universal indicator respectively.

\subsection{Statistical analysis}

Data was expressed as the mean \pm SE of three replicates. Data recorded during the Experiment for growth parameters was analyzed by One-way ANOVA. Significant difference was indicated as $p<0.05$, among the treatments means (Snedecor and Cochran, 1967; Zar, 2006). The means were compared by using one way ANNOVA. The post hoc analysis was carried out by using Student's Newman Keul (SNK) of difference are significant $p<0.05$.

\section{Results and Discussion}

The growth performance, survival, feed utilization and water parameters of tilapia fry fed on diet supplemented with fermented azolla is presented in Table 4 and Table 5 respectively. The results showed that the diet containing $20 \%$

Table 4: Growth performance, survival and feed utilization

\begin{tabular}{llcccl}
\hline SI. No. & Parameters & $\mathrm{T}_{0}$ & $\mathrm{~T}_{1}$ & $\mathrm{~T}_{2}$ & \multicolumn{1}{c}{$\mathrm{T}_{3}$} \\
\hline 1 & Length gain & $96.516 \pm 8.130$ & $111.242 \pm 8.774$ & $178.586 \pm 11.313$ & $153.285 \pm 20.041$ \\
2 & Weight gain & $927.346 \pm 43.982$ & $1055.130 \pm 118.616$ & $1346.770 \pm 70.251$ & $1213.740 \pm 49.069$ \\
3 & SGR & $3.879 \pm 0.073$ & $4.059 \pm 0.181$ & $4.449 \pm 0.083$ & $4.290 \pm 0.062$ \\
4 & ADG & $2.143 \pm 0.088$ & $2.327 \pm 0.107$ & $2.840 \pm 0.057$ & $2.588 \pm 0.059$ \\
5 & Survival & $80.000 \pm 1.925$ & $83.333 \pm 1.925$ & $95.556 \pm 2.222$ & $90.000 \pm 1.925$ \\
6. & FCR & $1.814 \pm 0.067$ & $1.556 \pm 0.048$ & $1.236 \pm 0.30$ & $1.359 \pm 0.042$ \\
7 & PER & $3.119 \pm 0.108$ & $3.517 \pm 0.395$ & $4.145 \pm 0.0169$ & $3.935 \pm 0.199$ \\
\hline
\end{tabular}

Table 5: Water parameters observations during study period

\begin{tabular}{lcc}
\hline Water parameters & Ranges & $\begin{array}{c}\text { Mean values } \\
( \pm \mathrm{SE})\end{array}$ \\
\hline Temperature $\left({ }^{\circ} \mathrm{C}\right)$ & $26-28$ & $26.07 \pm 0.19$ \\
$\mathrm{pH}$ & $6-7$ & $6.53 \pm 0.05$ \\
Dissolved oxygen $\left(\mathrm{mg} \mathrm{l}^{-1}\right)$ & $4-6$ & $5.83 \pm 0.12$ \\
Total alkalinity $\left(\mathrm{mg} \mathrm{l}^{-1}\right.$ as $\left.\mathrm{CaCO}_{3}\right)$ & $35-47$ & $43.23 \pm 0.06$ \\
Free carbon dioxide $\left(\mathrm{mg} \mathrm{l}^{-1}\right)$ & $1-3$ & $1.52 \pm 0.08$ \\
\hline
\end{tabular}

fermented azolla has shown showed highest growth, survival and feed utilization.
The present research work is focused on protein nutrition of farmed tilapia with emphasis on the use of non-conventional, under-utilized protein sources. Azolla, an aquatic floating fern, which is widely distributed throughout tropical and subtropical zones. It rapidly propagates and may doubles its biomass in 3-10 days reaching a standing crop of 8-10 t ha- ${ }^{-1}$ (Chen and Huang, 1987). This huge mass of high protein content has encouraged testing its use as fish fodder. Feeding tilapia with fresh or dried azolla has received special interest (Antoine et al., 1986; Pantastico et al., 1986; Antoine et al., 1987; Micha et al., 1988; Santiago et al., 1988 and El-Sayed and Teshima 1992). However, results were controversial. Various research studies have been conducted to evaluate the nutritional 
quality of azolla either in fresh or dry form. In majority of studies, azolla was used as a partial substitute for the costly protein rich sources. As per the results of the research investigations conducted by Antoine et al. (1986); Pantastico et al. (1986); Antoine et al. (1987); Micha et al. (1988); Santiago et al. (1988) and El-Sayedand Teshima (1992) have suggested that azolla can be effectively used as a feed ingredient. It can partially substitute the protein rich sources up to $30 \%$. In order to increase the digestibility of feed in totality and feed ingredient individually, fermentation with the help of yeast was carried out in the present study. Utomo and Ekasari (2011) have pointed out that the process of fermentation improves the nutritional qualities with reduction in crude fibre level and increase in protein content. Therefore, in the present study, preliminary trial experiment was conducted to study proper duration required for fermentation viz. 4, 6, 8 and 10 days. Comparing the protein content, it was found that 4 days fermentation with yeast in air tight container was sufficient with a peak in protein content. In the present study, the decreasing protein content was observed $5^{\text {th }}$ day onwards. The results of trial experiments are fully in agreement with Utomo and Ekasari (2011).

In the different feeding trials conducted by Shiomi and Kitoh (2001), Fiogbe et al. (2004) and Abou et al. (2008) for fry of tilapia, azolla meal incorporation levels between 15 to $20 \%$ were proved to be suitable in terms of growth performance. After statistical analysis of the present experimental data, it was also proved that about $20 \%$ (fermented azolla paste) can be effectively used as a partial substitute for fish meal.

In other species such as Tilapia zillii, the incorporation level up to $25 \%$ was suggested by Tawwab (2008). Azolla can be used as feed ingredient and can be used as a protein replacer in fish species viz. Labeo fimbriatus (40\%), Tor grypus (10\%) and Anabas testudineus (15\%) as stated by Gangadhar et al. (2015), Gokcinar and Bekcan (2015) and Mishra (2013) respectively.

Thus, based on the results of the present investigation and review of the earlier research works, it can be stated that fermented azolla can be efficiently substituted to fish meal up to $20 \%$ in dry form. In case of fermented azolla, the process of fermentation may increase the digestibility of nutrient subsequently feed ingredients and feed. This is evident from the results of the present study while comparing $T_{1}, T_{2}, T_{3}$ with $\mathrm{T}_{4}$. Therefore it is proposed to use fermented azolla paste as a feed ingredient to increase the digestibility of feed in terms of lower feed conversion ratio and higher protein efficiency ratio.

\section{Conclusion}

Nile tilapia (Oreochromis niloticus) fed with four isonitrogenous diet containing $30 \%$ crude protein in which fish meal was partially substituted $10 \%$ fermented azolla, $20 \%$ fermented azolla and $30 \%$ fermented azolla in that $20 \%$ fermented azolla showed better growth (length gain, weight gain and specific growth rate), survival and feed utilization such as feed conversion ratio (FCR) and protein efficiency ratio (PER) than other treatment during rearing for 60 days in laboratory condition.

\section{Acknowledgement}

The authors are thankful to the Collage of Fisheries Science, Shirgaon, Ratnagiri, DRBSKKV, Dapoli, for their support, suggestions and encouragement during the research.

\section{References}

Abou, Y., Fiogbe, E.D., Micha, J.C., 2008. A Preliminary Assessment of Growth and Production of Nile Tilapia, Oreochromis niloticus (L) fed Azolla Based Diets in Earthen Ponds. Journal of Applied Aquaculture 19, 55-69.DOI:10.1300/J028v19n04_03.

Antoine, T., Carraro, S., Micha, J.C., Van Hove, C., 1986. Comparative appetency for Azolla of Cichlasoma and Oreochromis (tilapia). Aquaculture 53, 95-99. DOI: 10.1016/0044-8486(86)90279-6.

Antoine, T., Wery, P., Micha, J.C., Van Hove, C., 1987. Comparison of the growth and chemical composition of Oreochromis niloticus (tilapia) and Cichlasoma melanurum (Theraps) fed with Azolla. Aquaculture 66, 181-196.

APHA, 2005. Standard Methods for the examination of water and waste water, 20th Edition, INC. Arlington, VA. 1-1134.

Bag, M.P., Mahapatra, S.C., 2012. Efficiency of fermented fish offal meal on growth and fatty acid profile of tilapia (Oreochromis niloticus).Elect. J. Biol. 8, 62-66.

Boyd, C.E., 1981. Water quality in warm water fish ponds. Auburn University, Alabama, USA: 1-359.

Cagauan, A.G., Pullin, R.S.V., 1991. Azolla in aquaculture: Past, present and future. In: J. Muir \& R.J. Roberts, (Eds.) Recent. Advances in Aquaculture. Oxford, Blackwell Sci. 104-130.

Chen, D.F., Huang, C.Y., 1987. Study on Azolla as a fish fodder. In Proceedings of the Workshop on Azolla use. International Rice Research Institute, Manila, 270.

El-Sayed, A.F.M., Teshima, S., 1992. Protein and energy requirement of Nile tilapia Oreochromis niloticus, fry. Aquaculture103, 55-63. DOI: 10.1016/00448486(92)90278-S

FAO, 2016. The state of world fisheries and aquaculture. Food and Agriculture Organization of the United Nations, Rome, 3-29.

FAO,2017. Global aquaculture production for world. 2014-2015. http://www.fao.org/figis/servlet/ SQServlet?file=/work/FIGIS/prod/webapps/figis/temp/ hqp_2760354180825706457.xml\&outtype=html, Rome.

Fasakin, E.A., Balogun, A.M., Fagbenro, O.A., 2008. Evaluation of Sun-dried water fern, Azolla africana and duckweed, Spirodela polyrrhiza in practical diets for Nile tilapia, Oreochromis niloticus fingerlings.Journal Applied 
Aquaculture. 11, 83-92. DOI: 10.1300/J028v11n04_09

Fiogbe, E.D., Micha, J.C., Van Hove, C., 2004. Use of a natural aquatic fern, Azolla microphylla, as a main component in food for the omnivorous phytoplanktonophagous tilapia, Oreochromis niloticus (L). Journalof Applied Ichthyology 20, 517-520. DOI: 10.1111/j.1439-0426.2004.00562.x

Gangadhar, B., Sridhar, N., Saurabh, S., Raghavendra, C.H., Hemaprasanth, K.P., Raghunath, M.R., Jayasankar, P., 2015. Effect of Azolla-incorporated diets on the growth and survival of Labeo fimbriatus during fry-to fingerling rearing. Cogent Food and Agriculture, 1-8. DOI: 10.108023311932.2015.1055539

Gokcinar, N.C., Bekcan. S., 2015. The effects of partially replacing fishmeal with Azolla (Azolla Sp.) on growth parameters of shabbout fish (Tor grypus H. 1843). Journal Applied Biological Science 9, 43-46.

Hardy, R.W., Tacon G.J., 2002. Fish meal: Historical uses, production trends and future outlooks for sustainable supplies, In: Stickney, R.R., Mcvey, J.P. (Eds), Responsible Marine Aquaculture, CABI publishing, New York, pp. 311-326.

Landau, M., 1992. Introduction to aquaculture. John Wiley and sons inc., New York.

Leonard, V., 1997: Use of Aquatic Fern (Azolla filiculoides) in Two Species of Tropical Fish (Oreochromis niloticus and Tilapia rendalli). PhD Thesis. Presses Universities the Namur, Belgium, 276.

Micha, J.C., Antoine, T., Wery, P., Van Hove, C., 1988. Growth ingestion capacity, comparative appetency and biochemical composition of Oreochromis niloticus and Tilapia rendalli fed with Azolla. In: Pullin, R.S., Bhukaswan, V.T., Tonguthai, K., Maclean, J.L. (Eds). The Second International Symposium on Tilapia in Aquaculture. ICLARM, Manila, Philippines, 347

Mishra, B., 2013. Effect of Azolla supplementation in the fish feed on the growth of Climbing perch, Anabas testudineus. American international Journal of Research Science, Technology, Engineering and Mathematics, 13-309.

Murkar, A.A., 2011. Effect of dietary protein and lipid level on growth, feed efficiency and survival of flowerhorn fish. M. F. Sc. Thesis, Dr. Balasaheb Sawant Kokan Krishi Vidyapeeth, Dapoli.

Ng, W.K., Chong, C.Y., 2004. An overview of lipid nutrition with emphasis on alternative lipid sources in tilapia feeds. Fish Nutrition Laboratory School of Biological Science
University Sains Malaysia Penang 11800, Malaysia.

Pantastico, J.B., Baldia, S.F., Reyes, D.M., 1986. Tilapia ( $T$. nilotica) and Azolla (A. pinnata) cage farming in Laguna Lake. Fisheries Research Journal Philippines 11, 21-28.

Santiago, C.B., Aldaba, M.B., Reyes, O.S., Laron, M.A., 1988. Response of Nile tilapia (Oreochromis niloticus) fry to diets containing Azolla meal. In: Pullin, R.S.V., Bhukaswan, T., Tonguthai, K., Maclean, J.L., (Eds). The Second International Symposium on Tilapia in Aquaculture. ICLARM, Manila, Philippines. 377-382.

Schulz, C., Bohm, M., Wirth, M., Rennert, B., 2007. Effect of dietary protein on growth, feed conversion, body composition and survival of pike pearch fingerlings (Sander lucioperca). Aquaculture nutrition 13, 373-380. DOI: 10.1111/j.1365-2095.2007.00487.x

Shiomi, N., Kitoh, S., 2001. Culture of Azolla in a pond, nutrient composition, and use as fish feed. Soil Science and Plant Nutrition 47, 27-34. DOI:10.1080/00380768.2001.104 08365.

Snedecor, G.W., Cochran, W.G., 1967. Statistical methods, 6th ed. Oxford and IBH publishing Co., New Delhi.

Stickney, R.R., 1997. Tilapia nutrition, feeds and feeding. Tilapia Aquaculture Ame. 1, 34-54.

Tawwab, M.A., 2008. The preference of the omnivorousmacrophagous, Tilapia zillii (Gervais), to consume a natural free-floating fern, Azolla pinnata. Journal of World Aquaculture Society 39, 104-112. DOI: 10.111/j.1749-7345.2007.00131.x.

Tacon, A.G.J., Metian M., 2009. Fishing for aquaculture: non-food use of small pelagic forage fish-a global perspective. Reviews Fisheries Science 17(3), 305-317. DOI: 10.1080/10641260802677074

Utomo, N.B.P., Ekasari, N.J., 2011.Fermentation of Azolla sp. leaves and the utilization as a feed ingredient of tilapia Oreochromis sp. Journal of Aquaculture Indonesia 10, 137-143.

Velasquez, Y.C., Kijora, C., Wuertz, S., Schulz, C., 2015. Effect of fermented aquatic macrophytes supplementation on growth performance, feed efficiency and digestibility of Nile tilapia (Oreochromis niloticus) juveniles fed low fishmeal diets. Livestock Research for Rural Development 27(9).

Zar, J.H., 2006. Biostatistical analysis. Prentice- Hall, Inc, Englewood cliffs, N.J., U.S.A. 